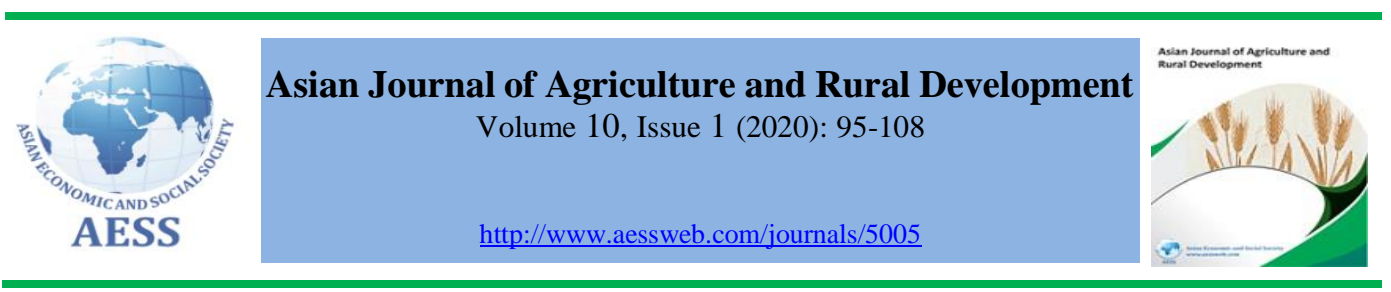

\title{
STRUCTURE AND PERFORMANCE OF ADVISORY SERVICES IN AGRICULTURAL DEVELOPMENT AROUND PROTECTED AREA: THE CASE OF XUAN THUY NATIONAL PARK, VIETNAM
}

\author{
Nguyen Thi Trang ${ }^{a}$ Economics \& Rural Development, Gembloux Agro-Bio \\ Nhung ${ }^{\text {b }} \mathbf{i}$, \\ Tech, University of Liège, Belgium \\ Tran Huu Cuong ${ }^{\text {b }}$, ${ }^{b}$ Faculty of Accounting and Business Management, \\ Philippe Lebailly ${ }^{\text {a }}$ Vietnam National University of Agriculture, Hanoi, \\ Vietnam
}

$\triangle$ thuytrangnhung@gmail.com (Corresponding author)

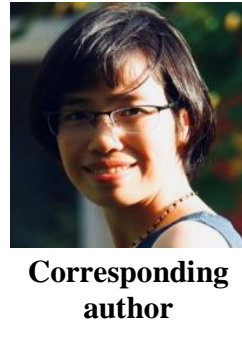

\section{ARTICLE HISTORY: \\ Received: 18-Dec-2019 \\ Accepted: 28-Feb-2020 \\ Online Available: 20-Mar- 2020}

\section{Keywords:}

Agricultural advisory services,

Buffer zone,

Xuan Thuy national park, Vietnam

\section{ABSTRACT}

The study was conducted in the buffer zone of Xuan Thuy National Park (XTNP), the largest wetland ecosystem in Northern Vietnam, to assess the governance structure and performance of agricultural advisory services (AAS) in agricultural production under the context of environmental protection. Based on a sample of 12 officials from diverse organizations and 234 farmers living nearby the park, the results revealed that agricultural production received supports from both public and private sectors, including communal agricultural board (CAB), communal agricultural cooperative (CAC), XTNP management board, irrigation companies, and input dealers. There were huge differences in advisory flows, methods, and effectiveness according to types of AAS providers and production systems. Rice production received more technology transferred from $\mathrm{CAC}, \mathrm{CAB}$ and irrigation companies as compared to aquaculture farming. Meanwhile, aquaculture sectors obtained more consultation from input dealers. Among public sectors, XTNP's managers were partly responsible for raising awareness of environmental protection of the inhabitants but this organization has a small role in the agricultural development of peripheral communities.

\begin{abstract}
Contribution/ Originality
This article contributes to overcome the shortage of information on agricultural advisory services for buffer zone management of Vietnam and other countries. In this manuscript, the authors analyse the governance structure of agricultural advisory services (AAS) in the buffer areas of Xuan Thuy national park of Vietnam. Then, performance of AAS was evaluated regarding the relevance and effectiveness of service providers with farmers.
\end{abstract}

DOI: 10.18488/journal.1005/2020.10.1/1005.1.95.108

ISSN (P): 2304-1455/ISSN (E):2224-4433

How to cite: Nguyen Thi Trang Nhung, Tran Huu Cuong and Philippe Lebailly (2020). Structure and performance of advisory services in agricultural development around protected area: the case of Xuan Thuy National Park, Vietnam. Asian Journal of Agriculture and Rural Development, 10(1), 81-94.

(C) 2020 Asian Economic and Social Society. All rights reserved. 


\section{INTRODUCTION}

Agricultural advisory services (AAS) (evolve from the extension) refer to the entire organizations assisting farmers to solve problems and obtain information, skills and technologies to enhance agricultural production and stimulate their livelihoods (Birkhaeuser et al., 1991; Anderson and Feder, 2007; Anderson, 2008, Regina et al., 2009). The initial objective of AAS is to stimulate farm productivity. In addition, AAS helps to reduce the gap between potential and actual yields through the technology transfer and provision of management skills. The enormous investment in advisory services has significant roles in the agricultural production of developing countries (Anderson, 2008). However, the decentralization of the extension system includes more involvement of the private sector and the third sector (non-government organizations and farmers' consortium) contributes to pluralistic forms of AAS (Sulaiman and Hall, 2002). Currently, AAS is reformed to confront changes in global food and farming system such as the expansion of supermarkets, developing standards and labels, increasing non-farm rural employment, agricultural industrialization and the degradation of natural resources, etc. (Anderson, 2008). Farmers acquire diverse advisory services incorporating technical, socio-economic and environmental parameters through the dissemination of information and technology, reinforcement of learning process, and accompanying interactions between stakeholders (Faure et al., 2012).

Vietnam has approximately 70 percent of households depend on agricultural activities which have linkages with advisory services (Hynek and Jana, 2019). Information transmission, training and other service supports are essential for rural development in developing countries including Vietnam (Ruifa et al., 2012; Mohsen and Kamal, 2012; Donus et al., 2013). The public AAS system was officially established in Vietnam in 1993 firstly to provide advanced technology and training and to disseminate agricultural-related policies (Bo, 2012). Currently, this public system operates nationwide with five administrative levels (central, provincial, district, commune and village) at an average ratio of one extension officer per 280 households to help farmers to improve grain yield through responding to outbreaks of pests or diseases and supporting the implementation of new varieties. Beside some achievements, public AAS sectors still have various limitations, including: (1) a shortage in the quantity of extensional workers as well as lack of qualified personnel; (2) a dearth of integrated specialized workers for whole production process; (3) AAS has not yet focused on processing and marketing; (4) its methods has not satisfied diverse demands of different farming systems; and (5) low participation of farmers in AAS system (Bo, 2012). Since 2015, Vietnam began transforming its AAS to improve efficiency as well as the competitiveness of agriculture and the livelihood of farmers (Ngan and Suresh, 2018). Pluralistic actors from private sectors participate in carrying out advisory tasks including farm households, common interest groups, and agribusiness enterprises. They provide formal and informal knowledge and contribute to the enhancement of social learning among communities.

Different farming systems require relevant information to gain higher productivity and profitability for the improvement of farmers' livelihoods (Singh et al., 2016). The buffer zone of Xuan Thuy national park (XTNP) has diverse agricultural systems comprising rice-based, integrated aquaculture-mangrove, and intensive shrimp. They cultivate in a changing environment. Being the buffer zone of the international importance site, the central government requires agricultural production to mitigate its impacts on the ecosystem at the same time ensure economic viability for farmers. However, attempts to integrate environmental protection in cultivation have met with limited success. Water conflicting between farmer users, excessive use of agrochemicals, un-treated sludge from farms is concerned by many researchers (Haneji, 2014; Nguyen et al., 2019, Nhung et al., 2020). Shortage of assistance, low effectiveness of AAS work and lack of collaboration between stakeholders partly prevents agricultural development toward conservation goals. The purposes of this article are to (1) describe the governance structure of AAS in Nam Dinh province 
and XTNP's buffer zone; (2) assess the performance AAS in agricultural development and (3) propose implication to enhance roles of AAS in this area.

\section{MATERIALS AND METHODS}

\subsection{Study site}

The study was conducted in the buffer communes surrounding Xuan Thuy national park (XTNP). The park extends from latitude $20^{\circ} 10^{\prime}$ to $20^{\circ} 15^{\prime}$ North and longitude $106^{\circ} 20^{\prime}$ to $106^{\circ} 32^{\prime}$ East in Giao Thuy district, Nam Dinh province, Vietnam (Vietnam Administration of Forestry, 2017). The core zone of XTNP covers 7,100 ha including two areas of terrestrial (3,100 ha) and wetland (4,000 ha). Overall, XTNP has seven ecosystem typologies, including tidal wetland with mangroves, tidal wetland without mangroves, aquaculture-mangrove farming, rice farming, sandy coastal line, tidal rivers, and estuary. The mangrove forest is an important ecosystem. There are two types of mangroves consisting of natural and planted. It ranges between eight to ten meters in height. They are three canopies and seven species of mangrove in this area. The planted mangroves include two species which are of lower stature at five meters. Mangroves also play crucial functions in the park as providing living conditions for habitats and other wetland species, especially for migratory birds. The buffer zone covers 8,000 ha including Ngan islet (the boundary runs from the lagoon dike to the Vop river canal), Bai Trong and five communes namely Giao Thien, Giao An, Giao Lac, Giao Xuan, and Giao Hai.

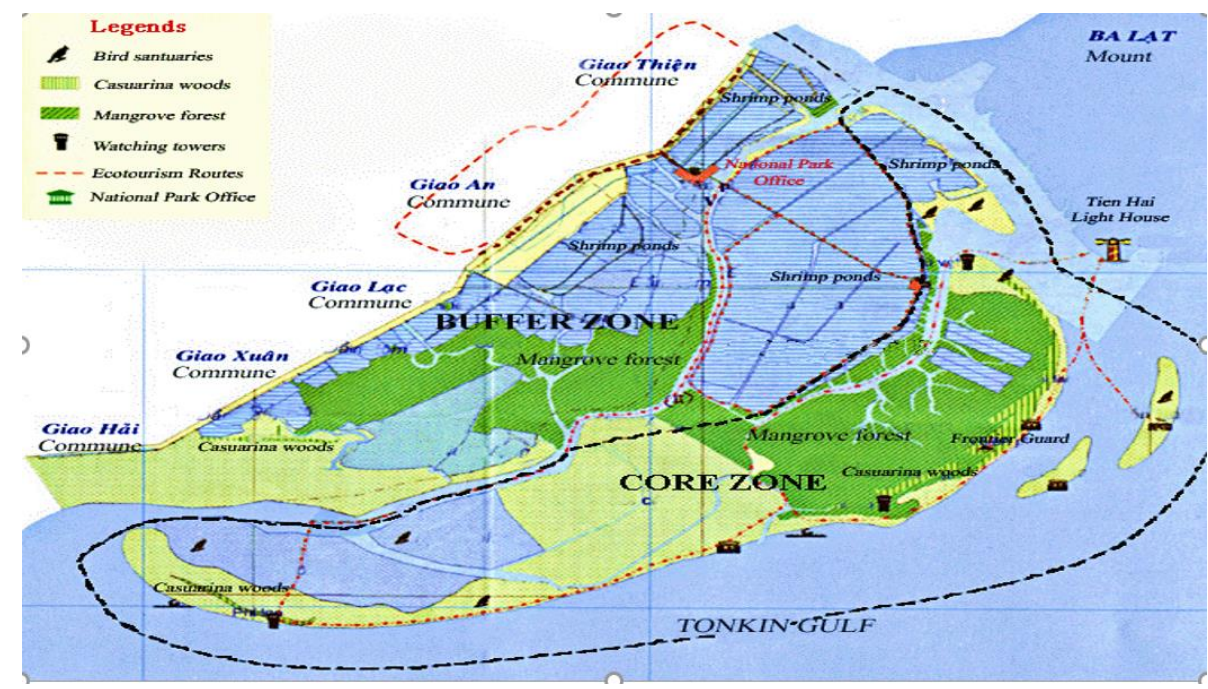

\section{Figure 1: Map of Xuan Thuy national park}

\subsection{Data collection and analysis}

The in-depth interviews were carried out in 2018-2019 to define the structure and organization of AAS in the study site. The surveys were conducted with managers of communal people's committee (CPC), headers of Communal Agricultural Board (CAB) and Communal Agricultural Cooperative (CAC), managers of XTNP management board and officials of Giao Thuy district's Department of Agriculture and Rural Development (DARD) and Center of Agricultural Services (CAS). In order to assess the organization and effectiveness of AAS, 234 farmers in major farming systems within the Ngan islet which is a large buffer area of XTNP were approached including Integrated aquaculture-mangrove (84 farmers), Intensive shrimp (54 farmers), and Rice-based (96 farmers) (Table 1). Questionnaires focused on advisory need and receive, farmers' perceptions of the effectiveness of AAS. 
Table 1: Distribution of respondents according to different farming systems

\begin{tabular}{lcc}
\hline Farming Systems & Total Farm Owners & No. of respondent \\
\hline Integrated aquaculture-mangrove & 102 & 84 \\
Intensive shrimp & 64 & 54 \\
Rice-based & 2737 & 96 \\
Total & 2903 & 234 \\
\hline
\end{tabular}

Farmers' opinion and knowledge on the effective level of AAS were evaluated by a weighted average index (WAI). The WAI is a social scaling for identifying the perception of farmers on aspects of sustainable agriculture (Zhen and Routray, 2003). This value can be estimated by multiplying the statement to its corresponding weight and dividing it by the total number of respondents in each farming systems (Chowdhury et al., 2015) as below:

$$
W A I=[\Sigma(V L * 0.2)+(L * 0.4)+(M * 0.6)+(H * 0.8)+(V H * 1.0)] / n
$$

where WAI $=$ the weighted average index $(0<\mathrm{WAI} \leq 1)$; VL $=$ number of farmers' response very low effectiveness and its weight is $0.2 ; \mathrm{L}=$ number of farmers' response low effectiveness and its weight is $0.4 ; \mathrm{M}=$ number of farmers' response very medium effectiveness and its weight is $0.6 ; \mathrm{H}$ $=$ number of farmers' response very high effectiveness and its weight is $0.8 ; \mathrm{VH}=$ number of farmers' response very high effectiveness and its weight is $1.0 ; \mathrm{n}=$ total number of respondents.

\section{RESULTS}

\subsection{Current farming practices}

\subsubsection{Integrated aquaculture - mangrove (IAM) production system}

The system combines extensive aquaculture species farming with mangrove trees. All of IAM farms were previously mangroves. Since 1986, mangroves were reduced to provide space for aquaculture raising. The average farm size was $6.82 \mathrm{ha} /$ farm owners, in which scattered mangroves were maintained with about $24.28 \%$ total area, as self-reported by respondents. Farm ranged in size from 2.2 to 20 ha. Black tiger shrimp (Penaeus monodon) and crab were reared in ponds. Numerous co-products such as wild-caught marines including shrimp (Metapenaeus ensis) and fish co-exist. Production cycle lasts from April to November, the remaining time (from December to March) farmland is open for brackish water with wild marines through the tide. In IAM culture, black tiger seed is hatchery-raised transporting from Ben Tre and Nha Trang provinces. However, $100 \%$ of crab seed were bought from farmers who involved in the exploitation of natural resources around XTNP wetland area. This production system was operated with little use of supplemental feeds (wet or dry pelleted feeds). There are not any antibiotics, fertilizers or other agrochemicals are used in this production.

\subsubsection{Intensive shrimp (ISH) production system}

Shrimp farms in XTNP's buffer zone situated in non-mangrove near rivers and Ba Lat estuary. Farms have an average size of 1.6 ha. A farm normally consists of several rearing ponds. One pond has a size of 1,000-1,500 m2. Pumps and two aeration device systems are available for water circulation in each pond. Farms depended on hatchery-raised seed. Farmers stocked whiteleg (Litopenaeus vannamei) at the rate of fries about 70-80 Post-larvae/m2. Grow-out takes about 80105 days for one seasons (two seasons/year). Farmers used commercial pellet feed for shrimp and numerous drugs and additives were also applied for water management. Water standards were tested before releasing post-larvae in all of the surveyed farmers. However, waste and sludge including uneaten feed, shrimp shells or organic and inorganic matter were often released to drainage canal or directly to surrounding rivers without careful treatment methods. 


\subsubsection{Rice-based (RB) production system}

Rice is planted in two crops per year without the application of crop rotation or intercropping. The first season usually lasts from January to May, and the second season starts from June to October. This system depends mainly on irrigation and rainfall. Rice production is small scale with 0.28 ha/household. From farmers' perspectives, high profitability and production yield are driving their decisions and the conservative objective is often seen as secondary by prevailing respondents. Pesticides were used by $100 \%$ of the respondents. Most of the rice grower burn straw after harvesting. All of the respondents used chemical fertilizers and there was an excessive use of nitrogenous nutrient sources. Agro-inputs were provided by $\mathrm{CAC}$ and private shops in communes. Cultivation is guided by DARD of Giao Thuy district, CAC and CAB. XTNP receives little political supports in monitoring unsustainable practices. Among 96 rice cultivators, there were 13 farmers $(13.5 \%)$ stated that they would increase the bio-pesticide amount in the fields.

\subsection{Governance structure of agricultural advisory services in Nam Dinh province and Xuan Thuy national park's buffer zone}

The governance structure implies the institutional set-up of the AAS system comprising public sectors (administrations and agencies), private sectors (farmers and profit-oriented enterprises), and the third sector (NGOs, farmer-based organizations, non-profit organizations) (Regina et al., 2009). Figure 2 illustrates the structure of AAS of Nam Dinh province including XTNP's buffer zone. There are a wide variety of stakeholders in the system including Department of Agriculture and Rural Development (DARD), Center of Agricultural Services (CAS), XTNP, agro-dealers (input traders) and irrigation companies.

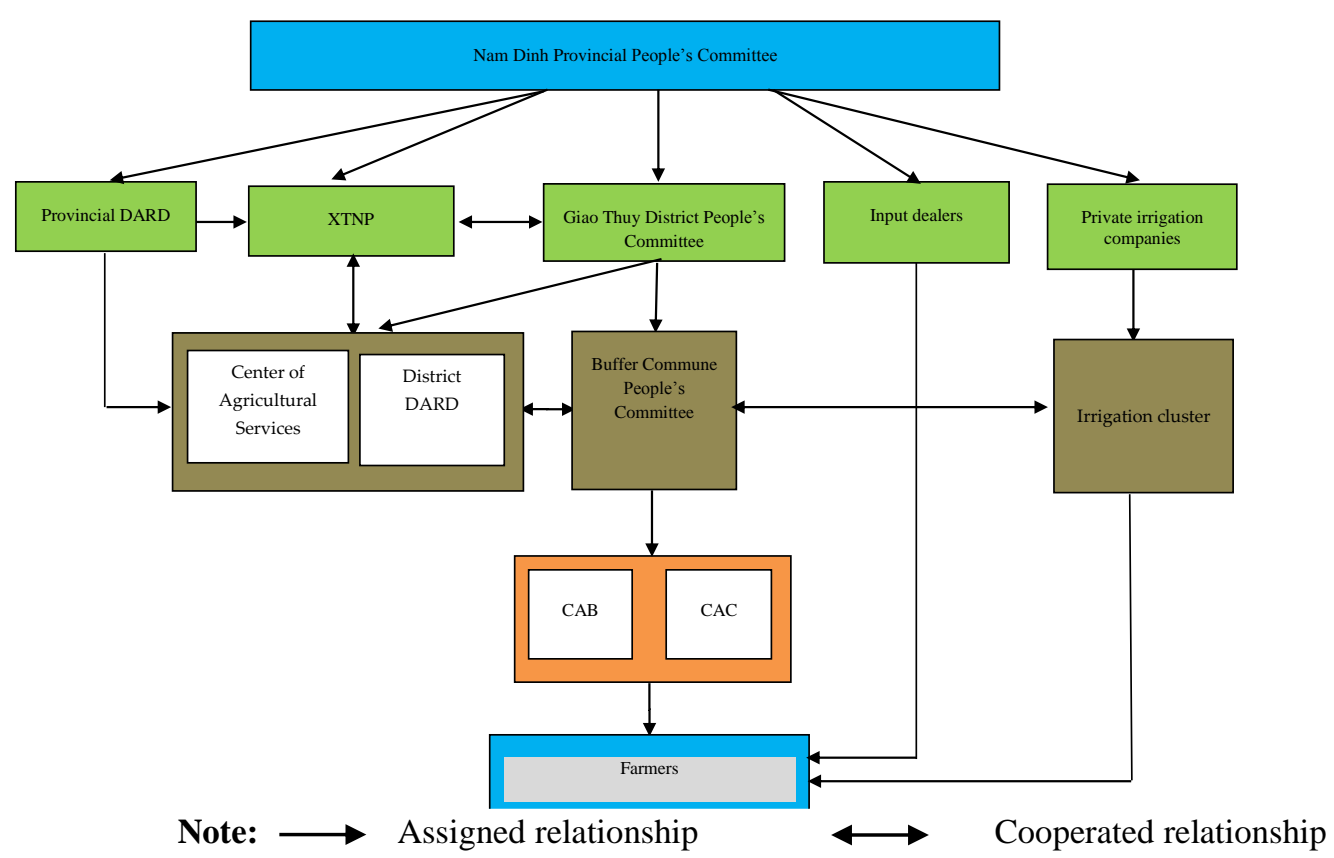

Figure 2: Stakeholders of the AAS system in Nam Dinh Province and Xuan Thuy national park's buffer zone

DARD: Department of Agriculture and Rural Development; XTNP: Xuan Thuy National Park;

CAB: Communal agricultural board; CAC: Communal agricultural cooperative. 
DARD and CAS are specialized agencies working under the authority of Giao Thuy District People's Committee. They coordinate with communes to promote agricultural production of the whole district. The main responsibilities of the DARD are defined by the Ministry of Agriculture and Rural Development and Ministry of Home Affairs ${ }^{1}$. It is in charge of: (1) implementing programs of agricultural, aquaculture, fishery and forestry development of the whole district; (2) controlling natural disasters, pest, and disease; (3) protecting irrigation infrastructure; (5) managing services to promote agriculture, forestry, aquaculture. The Nam Dinh Provincial People's Committee defines responsibilities of Center of Agricultural Service ${ }^{2}$ as (1) implementing programs of crop cultivation, plant protection, veterinary service provision, and agricultural extension of the whole district; (2) transferring advanced technologies for agricultural production; (3) organizing training for rural communities and (4) providing technical knowledge of crop cultivation, plant protection, and livestock raising.

At the commune level, Communal People's Committee (CPC) designates communal agricultural board $(\mathrm{CAB})$ and communal agricultural cooperative $(\mathrm{CAC})$. The $\mathrm{CAC}$ works under Cooperative Law $^{3}$ to supply agricultural materials and transferring knowledge for members. CAC has approached only rice farmers and it does not cover market development tasks. The CAB mainly instruct the cultivation, livestock raising activities, food safety programs and rural development of the commune.

A large number of private sectors facilitate in promoting agricultural and aquaculture production including irrigation companies, input enterprises, distributors and agro-dealers/traders. Enormous topics related to advanced agriculture and aquaculture are transferred to farmers through input traders. They offer comprehensive services directly for farmers including technical advice on the application of inputs in production. Irrigation is responsible for managing water in the region. They inform irrigation calendar to CAC and CBA and then irrigated water is provided directly to fields.

\subsection{Flows and methods of agricultural advisory services}

Figure 3-5 shows major multi-directional flows of advisory services and agricultural topics received by different groups of farmers. The role of public and private providers was different among the three groups of producers. The main findings show that the public AAS currently focuses almost on RB production with the main topics on conventional agriculture and less concern on conservation agriculture such as IPM or sustainable practices. The focus on conventional farming is based on raising productivity strategies of Nam Dinh People's Committee. Our further results reported that $100 \%$ of surveyed RB farms are cultivated with chemical fertilizers. Moreover, there has been excessive use of nitrogen-based fertilizers in rice production, compared with local standard introduced by DARD of Giao Thuy district (Nguyen et al., 2019). The standards for chemical fertilizers in XTNP area are recommended but not monitored by any institution. Extension staff from $\mathrm{CAB}$ have made little effort to decrease the use of chemical fertilizers and pesticides which mainly transfer through one-way propagation news on local radio. While CAC worked as a business unit to sell agricultural inputs and provide extension services for only RB cultivators and it has made more effect on promoting conservation agriculture knowledge through direct communication with farmers while selling input as compared with $\mathrm{CAB}$. CAB sometimes

\footnotetext{
${ }^{1}$ Circular 14/2015/TTLT-BNNPTNT-BNV of Ministry of Agriculture and Rural Development and Ministry of Home Affairs: Guidelines of responsibilities and structure of agricultural organizations of provincial and district levels. Available at https://thuvienphapluat.vn/van-ban/bo-may-hanh-chinh/Thong-tu-lien-tich-142015-TTLT-BNNPTNT-BNV-co-quan-chuyen-mon-ve-nong-nghiep-phat-trien-nong-thon-269221.aspx

${ }^{2}$ Decision 2721/2018/QD-UBND of Nam Dinh Provincial People's Committee: The establishment of Center of Agricultural Services of Giao Thuy district, Nam Dinh province. Available at http://sokhdt.namdinh.gov.vn/Filedinhkem/031220180238Giao\%20Thuy.PDF

3 Cooperative Law 23/2012/QH13 of Vietnamese Pariliament issued in 2012. Available at http://vanban.chinhphu.vn/portal/page/portal/chinhphu/hethongvanban?class_id=1\&mode=detail\&document_i $\mathrm{d}=164954$
} 
connect with private input suppliers organized meetings or training to promote companies' input products and disseminate rice production-related information. The shortage of staff holding aquatic expertise prevents both $\mathrm{CAB}$ and $\mathrm{CAC}$ from providing farming management knowledge and skills for IAM and ISH.

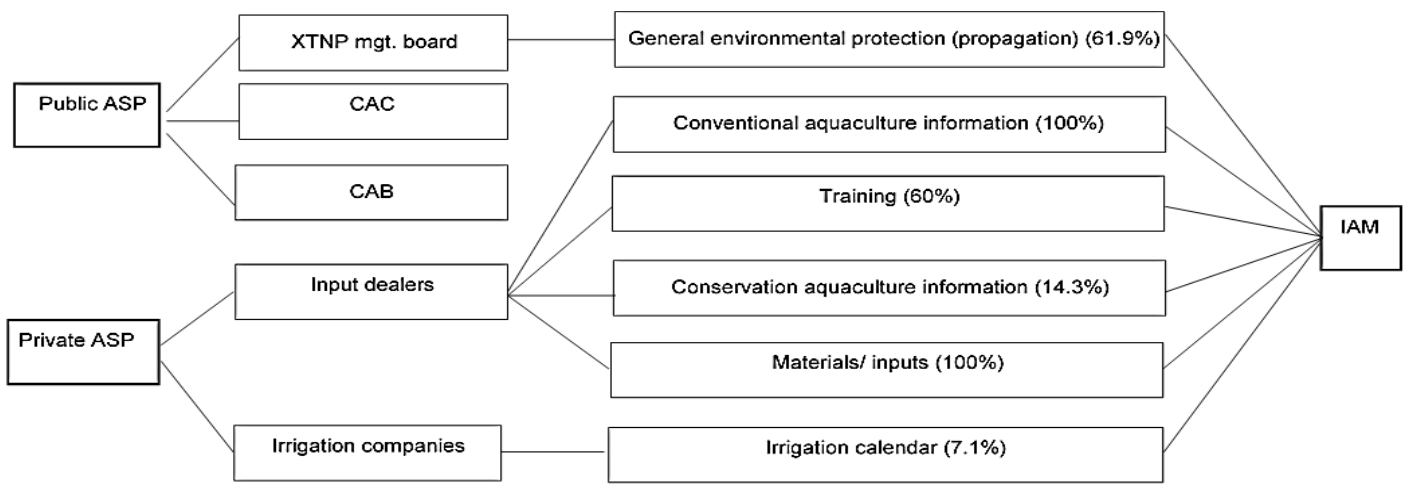

Figure 3: Advisory service flows for IAM farmers (\% of respondents)

Note: ASP: Advisory service providers. XTNP mgt. board: Xuan Thuy National Park management board; CAC: Communal Agricultural Cooperative; CAB: Communal Agricultural Board; IAM: Integrated Aquaculture Mangrove

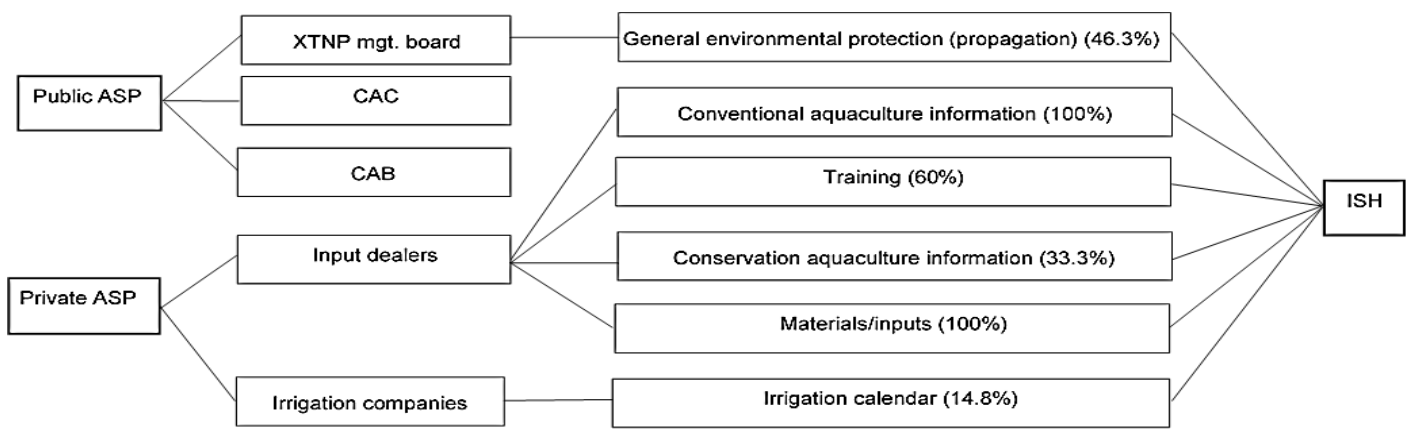

Figure 4: Advisory service flows for ISH farmers (\% of respondents)

Note: ASP: Advisory service providers. XTNP mgt. board: Xuan Thuy National Park management board; CAC: Communal Agricultural Cooperative; CAB: Communal Agricultural Board; ISH: Intensive Shrimp

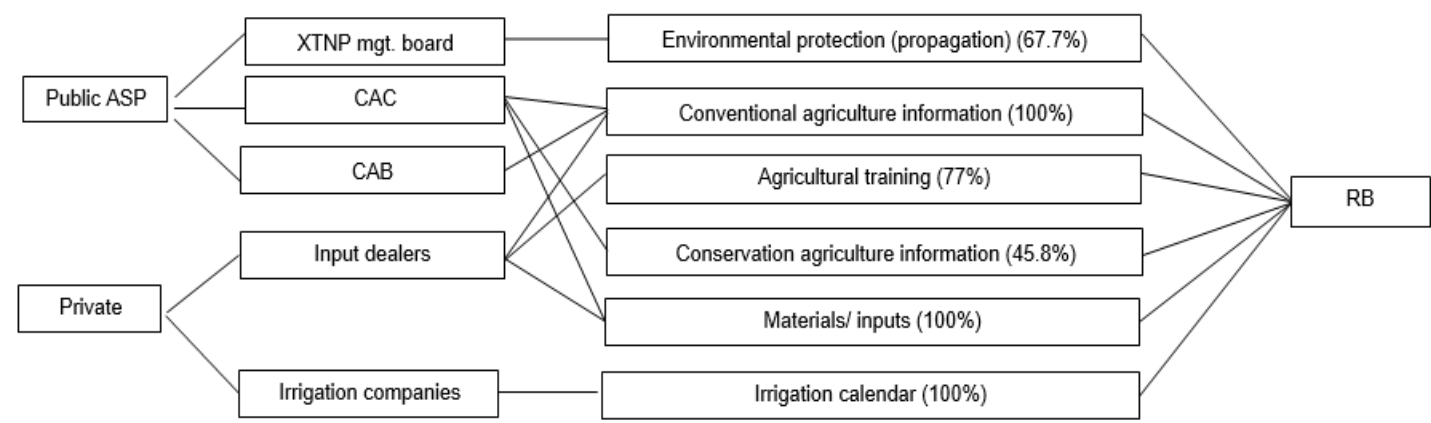

Figure 5: Advisory service flows for RB farmers (\% of respondents)

Note: ASP: Advisory service providers. XTNP mgt. board: Xuan Thuy National Park management board; CAC: Communal Agricultural Cooperative; CAB: Communal Agricultural Board; RB: Rice-based 
It was found that private input suppliers transferred various kinds of services including disseminating conventional and conservation agriculture knowledge, training, input provision. Private companies have extension workers holding specialization in agriculture, aquaculture, veterinary or economics. They often visit and help farmers to find the problems and solutions based on the participation of farmers. The role of private input supply companies has been increasing in the IAM and ISH farming with the dissemination of materials, new technology, and training based on a demand-driven approach. Distribution of feeds, additive nutrients and diverse artificial inputs for aquaculture production is carried by staff experts of national and international companies (Vinh Thinh, Bayer, etc.).

Irrigation companies are responsible for water management and informing the timetable of irrigation gates for merely RB growers through CAB and CAC. Nevertheless, the majority of IAM and ISH farmers cannot access irrigation services. They manage brackish water for their ponds through private communication or personal relationships with irrigation staff. This leads to frequent complaints by ISH and IAM on negatively affected by freshwater and pesticide residue from RB areas.

One indication that no sample farmers have interaction with XTNP's staff regarding agricultural activities but the park's authority is connected with farmers to educate and propagate three groups of farmers to preserve the living environments, such as garbage managing, bird conservation, and growing trees.

Advisory methods used by extension staff are plentiful depending on types of training and technology transfer (field days, demonstrations, short courses), number of farmers approached (individual, group, mass approach), participation of farmers (top-down and participatory methods), and specificity of farming (cropping, livestock, aquaculture), media (radio, paper, communication technology) (Regina et al., 2009; Cathrine et al., 2015). Table 2 shows methods and tools of AAS in XTNP's buffer zone. Input dealers have more types of delivery methods than XTNP, CAB, CAC, and irrigation companies according to three groups of farmers such as meeting, training, field visits, one-to-one advice, etc.

Table 2: Methods and tools of AAS to farmers

\begin{tabular}{|c|c|c|c|}
\hline \multirow{2}{*}{$\begin{array}{l}\text { Service } \\
\text { providers }\end{array}$} & \multicolumn{3}{|c|}{ Methods and tools } \\
\hline & IAM & ISH & RB \\
\hline Input dealers & $\begin{array}{l}\text { Meetings, training } \\
\text { courses, and selling }\end{array}$ & $\begin{array}{l}\text { Meetings, training courses, field } \\
\text { visits, one-to-one advice, input } \\
\text { supplier technicians, selling }\end{array}$ & $\begin{array}{l}\text { Training courses, } \\
\text { selling, and direct } \\
\text { consultation }\end{array}$ \\
\hline $\begin{array}{l}\text { Irrigation } \\
\text { companies }\end{array}$ & $\begin{array}{l}\text { Informing working } \\
\text { times of sluice gates } \\
\text { through public } \\
\text { loudspeakers }\end{array}$ & $\begin{array}{c}\text { Informing irrigation times of } \\
\text { sluice gates through public } \\
\text { loudspeakers }\end{array}$ & $\begin{array}{l}\text { Informing irrigation } \\
\text { times of sluice gates } \\
\text { through public } \\
\text { loudspeakers }\end{array}$ \\
\hline XTNP mgt. board & Meetings, training & Meetings, training & Meetings, training \\
\hline $\mathrm{CAB}$ & None & None & Public loudspeakers \\
\hline $\mathrm{CAC}$ & None & None & $\begin{array}{l}\text { Input supplying, direct } \\
\text { consultation }\end{array}$ \\
\hline
\end{tabular}

\subsection{Performances of agricultural advisory services (relevance of AAS)}

\subsubsection{AAS needs}

According to Regina et al. (2009), the performance of AAS can be assessed through the accuracy and relevance of the advisory content, timeliness of services, quality of the relationships or feedback, or efficiency of service dissemination. Table 3 illustrates various advisory services needed regarding different groups. The majority of IAM and ISH culturists expected solutions to 
their intake water, which has been impaired for months applying pesticides in RB fields and effluent discharge from ISH ponds. The present results further show that all of RB farmers widely applied pesticides, herbicides and fungicides. The majority of farmers $(80.21 \%$ of the respondents) used herbicides to kill weed species. Environmentally-friendly pest, disease and weed control methods were not largely applied by farmers. A further indication that can be observed is an overuse of nitrogen-based fertilizers and an imbalance rate of chemical fertilizers in the paddy field. RB cultivators needed extension people to address numerous problems that they cannot tackle individually including the spread of exotic snails and disease outbreaks, over dependent on chemical fertilizers and pesticides.

Table 3: Main topics of AAS needs

\begin{tabular}{lc}
\multicolumn{1}{c}{ AAS needs } & Percent (\%) \\
\hline 1. IAM (n=84) & \\
Controlling of pesticide contaminants from rice farms & 90.47 \\
Controlling effluent from ISH ponds & 33.33 \\
Monitoring post-larvae quality & 14.28 \\
Marketing, certification & 72.62 \\
Disease outbreak management skills & 10.71 \\
Drastic weather adaptation skills & 100.00 \\
2. ISH (n=54) & 77.78 \\
Controlling of pesticide contaminants from rice farms & 100.00 \\
Controlling effluent from ISH ponds & 100.00 \\
Monitoring post-larvae quality & 38.89 \\
Disease outbreak management skills & 68.52 \\
Credit access supports & 100.00 \\
Drastic weather adaptation skills & \\
3. $R B(n=96)$ & 63.54 \\
Disease outbreak adaptation & 73.96 \\
Solutions for decreasing in use of chemical fertilizers & 100.00 \\
Solutions for decreasing in use of pesticide & 100.00 \\
Controlling of exotic snails & 21.88 \\
Drastic weather adaptation skills & \\
\hline
\end{tabular}

Natural disaster adaptation skills related are also mostly requested by IAM, ISH culturists and some of RB growers, since their farms are located near the coastline which has been affected by climate variability including storms, fluctuation of salinity and climate changes. Post-larvae quality monitoring is another emerging problem required to be tackled by ISH and some IAM farmers.

\subsubsection{AAS receipt}

Farmers were asked for advisories obtained from agricultural extension people. One indication reveals that government-based actors of $\mathrm{CAB}$ and $\mathrm{CAC}$ have been reaching a significant proportion of rice farming populations on a sustained basis with information and guidance on the use of farm inputs, while both aquaculture raising groups were limited to access transferred works from these providers. On the other hand, private input suppliers played an important role with respect to providing knowledge and facilitate consultation on pond and feed management for two groups of IAM and ISH. Irrigation time of opening and closing the sluice system was available for all of RB but for moderate percent of IAM and ISH (Table 4). 
Table 4: Main topics of AAS receipt

\begin{tabular}{lcc}
\hline AAS receipt & Percent (\%) & Providers \\
\hline 1.IAM $(n=84)$ & & \\
Shrimp larvae management & 100.00 & Private input dealers \\
Pelletized feed use & 100.00 & Private input dealers \\
Irrigation calendar & 7.10 & Irrigation staff, CAB \\
Training & 60.71 & Private input dealers \\
2.ISH $(n=54)$ & & \\
Shrimp larvae management & 100.00 & Private input dealers \\
Pelletized feed use & 100.00 & Private input dealers \\
Pond management & 100.00 & Private input dealers \\
Veterinary medicine application & 100.00 & Private input dealers \\
Disease adaptation skills & 100.00 & Private input dealers \\
Training & 100.00 & Private input dealers \\
Irrigation calendar & 14.80 & Irrigation staff, CAB \\
3.RB $(n=96)$ & & \\
Pesticide application & 100.00 & CAB, CAC \\
Fertilizer application & 100.00 & CAB, CAC \\
Crop calendar & 100.00 & CAB, CAC \\
Training & 77.08 & CAB, input dealers \\
Irrigation calendar & 100.00 & CAB, CAC, irrigation staff \\
\hline
\end{tabular}

\subsubsection{Effectiveness of AAS}

An assessment of effective levels of AAS is to provide evidence from advisories at the regional level. Farmers were asked whether they were aware of effective levels of AAS provision in terms of technical and non-technical services. Responses were ranked as very high, high, medium, low, and very low as presented below:

Table 5: Value index of effective level from the farmers' perspective

\begin{tabular}{lcccccc}
\hline & $\begin{array}{c}\text { Very } \\
\text { high }(\mathbf{1 . 0})\end{array}$ & $\begin{array}{c}\text { High } \\
(\mathbf{0 . 8})\end{array}$ & $\begin{array}{c}\text { Medium } \\
(\mathbf{0 . 6})\end{array}$ & $\begin{array}{c}\text { Low } \\
(\mathbf{0 . 4})\end{array}$ & $\begin{array}{c}\text { Very low } \\
(\mathbf{0 . 2})\end{array}$ & WAI \\
\hline 1. IAM farmers & number of respondents) & & & & \\
CAC & 0 & 0 & 14 & 70 & 0 & 0.43 \\
CAB & 0 & 0 & 4 & 80 & 0 & 0.41 \\
XTNP & 0 & 0 & 11 & 73 & 0 & 0.42 \\
Irrigation board & 0 & 0 & 17 & 67 & 0 & 0.44 \\
Input dealers & 0 & 61 & 12 & 11 & 0 & 0.72 \\
2. ISH farmers (number & of respondents) & & & & \\
CAC & 0 & 0 & 6 & 48 & 0 & 0.42 \\
CAB & 0 & 0 & 4 & 50 & 0 & 0.41 \\
XTNP & 0 & 0 & 3 & 51 & 0 & 0.41 \\
Irrigation board & 0 & 0 & 7 & 47 & 0 & 0.43 \\
Input dealers & 0 & 39 & 15 & 0 & 0 & 0.74 \\
\hline 3. RB farmers (number of respondents) & 51 & 45 & 0 & 0 & 0.71 \\
CAC & 0 & 51 & 61 & 30 & 0 & 0.55 \\
CAB & 0 & 5 & 31 & 65 & 0 & 0.46 \\
XTNP & 0 & 0 & 59 & 0 & 0 & 0.68 \\
Irrigation board & 0 & 37 & 83 & 0 & 0 & 0.63 \\
Input dealers & 0 & 13 & & & & \\
\hline
\end{tabular}

Table 5 demonstrates different levels of farmers' perception of effectiveness from service providers. CAC, CAB, XTNP and irrigation companies gained higher effectiveness in the case of 
RB than IAM and ISH, nevertheless, input dealers are essential for two aquaculture farming groups. XTNP has low responding in the delivering agriculture advisory for three groups of farmers. The AAS works for RB, which focuses more on supplying seed, pesticides, fertilizers and informing cropping calendar. Meanwhile, there is shortage of transferred work for IAM and ISH because the communal authority has a lack of aquaculture technicians and field workers. AAS providers have few roles in assisting farmers to confront regional issues including negative impacts from pesticide contaminants and pond effluents, a disease outbreak in production, drastic weather, post-larvae quality management. On the other side, input dealers contribute growing roles in delivering materials and updated technical knowledge, instructing new technologies and providing direct consultation based on community-led and demand-driven approach for farmer clients in particular in the case of IAM and ISH.

\section{DISCUSSION}

Buffer areas are established to protect and enhance the conservation value of the parks or reserve (Lynagh and Urich, 2002). In particular, this zone of XTNP has objectives of (1) preventing threats from surrounding areas for the core zone, protecting forest trees, ecosystem, and biodiversity; (2) conservation of culture, indigenous knowledge, local gene and local breed and (3) heightening awareness of local managers and communities toward sustainable natural resource management and improving livelihood for residents. Results demonstrate that in the period from 2017-2019, XTNP management board has been implemented several activities to promote environmental protection in core and buffer zones, including environmental education, forest replanting, and ecotourism development. While the government aims at developing agriculture simultaneously ensuring biodiversity conservation for the park, nearby population manage their farms towards short-term profitability rather than long-term development. Currently, the ecosystem of this area bears many environmental impacts partly due to improper practices of farmers. As concerned by Nguyen et al., 2019, RB farmers apply excessive doses of inorganic fertilizers but dearth of organic nutrient sources. Contaminants of pesticides from RB fields were pollutants for IAM and ISH farm. Sludge and sewage without careful treatment from ISH ponds lead to degradation of intake water for both ISH and IAM. The findings of this study reveal that farming practices and management are guided by DARD of Giao Thuy district and applied similarly between buffer and outer communes of the district. The DARD regulates standards and permits of farm disposal based on index introduced by the Ministry of Agriculture and Rural Development of Vietnam in Circular number 22/2014/TTBNNPTNT (MARD, 2014) but they are implemented as a suggestion instead of a compulsion among farmers. This may mismatch between dual goals of XTNP's buffer areas which seek to achieve the livelihood of farmers and preserve the ecosystem.

The AAS system in the buffer zones of XTNP involves public and private stakeholders. They are crucial in promoting agricultural production by providing materials and disseminating knowledge and practices for classes of farmers. Public AAS providers have reached a number of marginal farmers, but their methods and flows remain a supply-driven approach with single technical services. Private actors carry out AAS but they may focus more on the needs of business than sustainability. According to Umali and Schwartz (1994), the public sector should provide advisory services if the advice has the nature of public goods, while the private sector is a preferred choice if the advice represents private goods. In addition, as mentioned by Boyd (2004) and Oladosu (2006), advisory service system is designed to help farmers to identify problems, educate and link them with the environment. Thus, it is urgent for more programs in conservation agriculture and water conflicting resolutions should be implemented and monitored strictly by government-based sectors. In addition, strengthening the collaboration between public and private sectors can complement and supplement of AAS system in the area and encourage multi-directional flows of information, knowledge and management skills. 
Since agricultural production in the buffer zone depends on changing conditions and needs of farmers for knowledge and information are various, but the AAS received is still poorly delivered for all farming systems. AAS focuses mainly on conventional than on conservative perspectives. Hence, current technical advisory has not improved the economic and environmental outcomes of diverse production systems. Target farm management skills, training, and solutions for different groups of farmers should be addressed based on the need for farmers to motivate farm managers to comprehensively adapt for sustainable production.

\section{CONCLUSION}

Vietnam, innovation in agricultural expertise and its application in agricultural production has been a significant contributor to economic growth. The overall objective of the AAS analysis is to provide an analysis of the structure and performance of AAS in protected areas' buffer zones of Vietnam. Results from individual surveys provide information on the implementation of AAS in different types of production systems for vision of further improvement.

There are two sectors involving in financing and transferring AAS in the study area comprising the public sector (CAB, CAC and XTNP management board) and the private sector (irrigation companies, input suppliers, distributors and agro-dealers selling pesticides, seeds, nutrients, and farm implements). Assessment of differences between AAS providers varied for diverse farming systems across the buffer areas. The public sector has municipal agriculture offices from central, province, district and commune levels. At the commune level, $\mathrm{CAB}$ and $\mathrm{CAC}$ play a vital role in promoting basic knowledge on conventional agriculture and training for a large proportion of $\mathrm{RB}$ growers. However, IAM and ISH farmers were limited to access services from these providers. Currently, private input suppliers have been reaching commercial aquaculture producers widely than smallholding RB farmers. The effective level of this input suppliers in IAM and ISH production is more than that of $\mathrm{CAB}$ and CAC. Among public sectors, XTNP's managers were partly responsible for raising awareness on environmental protection of inhabitants based on general environmental policies of state government but this organization has a small role in agricultural production of peripheral communities. The collaboration of XTNP with buffer communities was limited in agricultural production. Diverse production systems produce different products for farmer livelihood but various environmental problems incorporated with farm activities within the region. Collaboration between the public and private sectors and between XTNP's officials and buffer communes in strengthening conservation agriculture is necessary for better AAS in the site. Plus, practical technical assistance and solutions need to be redefined for each farming system to reduce the gaps of AAS need and receipt.

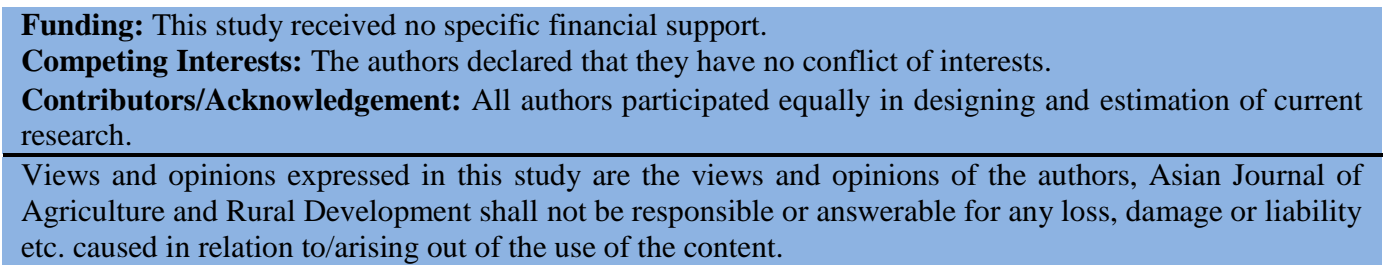

\section{References}

Anderson, J. R. (2008). Agricultural advisory services: A background paper for innovating through science and technology. Background paper for the world development report. Available at http://siteresources.worldbank.org/INTWDR2008/Resources/27950871191427986785/Ande rson_AdvisoryServices.pdf.

Anderson, J. R., \& Feder, G. (2007). Agricultural extension. Handbook of Agricultural Economics, 3, 2343-2378. 
Birkhaeuser, D., Evenson, R. E., \& Feder, G. (1991). The economic impact of agricultural extension: A review. Economic Development and Cultural Change, 39(3), 607-650. doi.org/10.1086/451893.

Bo, N. V. (2012). Agricultural Extension in Vietnam: Its roles, problems and opportunities. Proceedings of The Roundtable Consultation on agricultural extension for strengthening sustainable agriculture and farmers' participation in value chains in Asia. Syngenta Foundation for Sustainable Agriculture and Chinese Academy of Agricultural Science. Beijing, China. March 15-16, 2012.

Boyd, B. L. (2004). Extension agents as administrators of volunteers: Competencies needed for the future. Journal of Extension, 42(2), 23-31.

Donus, K. B., Kwabena, A. A., \& Joseph, A. K. (2013). Farmers' perceptions of the quality of extension services provided by non-governmental organisations in two municipalities in the Central region of Ghana. Agricultural System, 120, 20-26. doi.org/10.1016/j.agsy.2013.05.002.

Cathrine, R., John, U., Josee, R., \& Thaddee, B. (2015). Factor affecting performance of agricultural extension: evidence from Democratic Republic of Congo. The Journal of Education and Extension, 22(2), 113-143. doi.org/10.1080/1389224x.2015.1026363.

Chowdhury, M. A., Khairun, Y., \& Shivakoti, G. P. (2015). Indicator-based sustainability assessment of shrimp farming: a case for extensive culture methods in South-western coastal Bangladesh. International Journal of Sustainable Development, 18(4), 261-281. doi.org/10.1504/ijsd.2015.072646.

Faure, G., Desjeux, Y., \& Gasselin, P. (2012). New challenges in agricultural advisory services from a research perspective: A literature review, synthesis and research agenda. The Journal of Agricultural Education and Extension, 18(5), 461- 492. doi.org/10.1080/1389224x.2012.707063.

Haneji, C. (2014). Analysis of environmental stressors on ecosystems of Xuan Thuy national park, Vietnam. Journal of Vietnamese Environment, 5(1), 12-21.

Hynek, R., \& Jana, M. (2019). Identification of context-specific knowledge as a tool for biogas facilitators and their quality involvement-using Vietnamese practice as an example. Energies, 12(7), 1326-1336. doi.org/10.3390/en12071326.

Lynagh, F. M., \& Urich, P. B. (2002). A critical review of buffer zone theory and practice: A Philippine case study. Society \& Natural Resources, 15(2), 129-145.

MARD (Ministry of Agriculture and Rural Development). (2014). Circular 22/2014/TTBNNPTNT: National technical regulation on brackish water shrimp culture farm-conditions for veterinary hygiene. Environmental protection and food safety.

Mohsen, N., \& Kamal, D. (2012). Study obstacles and problems of agriculture extension training courses from extension workers points of view participating in the extension training courses Dezful city. Procedia - Social and Behavioral Science, 46, 5707-5713. doi.org/10.1016/j.sbspro.2012.06.502.

Ngan, P. H., \& Suresh, C. B. (2018). Agriculture extension in Vietnam: An assessment and reform options. A discussion paper of International Food Policy Research Institute (IFPRI), Washington, DC 20005-3915 USA.

Nguyen, T. T. N., Tran, H. C., Ho, T. M. H., Burney, P., \& Lebailly, P. (2019). Dynamics of farming systems under the context of coastal zone development: the case of Xuan Thuy National Park, Vietnam. Agriculture, 9(7), 138-157. doi.org/10.3390/agriculture9070138.

Nhung, N. T. T., Cuong, T. H., Burney, P., Hop, H. T. M., Dogot, T., \& Lebailly, P. (2020). Economic analysis of different aquaculture systems in coastal buffer zones of protected areas: a case study in Xuan Thuy National Park, Vietnam. Ecology, Environment and Conservation, 26(2), 44-52.

Oladosu, I. (2006). Implications of farmers' attitude towards extension agents on future extension programme planning in Oyo state of Nigeria. Journal of Social Science, 12, 115-118. doi.org/10.1080/09718923.2006.11978377. 
Regina, B., Kristin, D., John, P., Epharaim, N., Ponniah, A., Javier, E., Adiel, M., David, J. S., Daniela, H., Samuel, B. \& Marc, C. (2009). From best practice to best fit: a framework for designing and analyzing pluralistic agricultural advisory services worldwide. The Journal of Agricultural Education and Extension, 15(4), 341-355. doi.org/10.2499/bestfitibrb04

Ruifa, H., Yaqing, C., Kevin, Z. C., Chen, J. H. (2012). Effects of inclusive public agricultural extension service: Results from a policy reform experiment in western China. China Economic Review, 23(4), 962-974. doi.org/10.1016/j.chieco.2012.04.014.

Singh, K. M., Shahi, B., \& Singh, P. (2016). Role of private advisory services in agricultural extension: a review. Journal of AgriSearch, 3(3), 191-194. doi.org/10.21921/jas.v3i3.11384.

Sulaiman, V., \& Hall, A. (2002). Beyond technology dissemination-can Indian agricultural extension re-invent itself? National Center for Agricultural Economics and Policy Research. New Delhi, India.

Umali, D. L., \& Schwartz, L. (1994). Public and private agricultural extension: Beyond traditional frontiers. World Bank discussion papers no.236, April. Washington, D.C, 20433, USA.

Vietnam Administration of Forestry. (2017). National parks of Vietnam. Ha Noi: Vietnam Association of National Park and Nature Reserve.

Zhen, L., \& Routray, J. K. (2003). Operational indicators for measuring agricultural sustainability in developing countries. Environmental Management, 32(1), 34-46. doi.org/10.1007/s00267003-2881-1. 